\title{
Deskripsi Sosial Masyarakat terhadap Gambar dan Tulisan yang Terdapat dalam Gerobak Truk
}

\author{
Asih Prihandini \\ Universitas Komputer Indonesia, Jl. Dipatiukur 112-116 Bandung, asih.prihandini@email.unikom.ac.id
}

\author{
Ahmad Fauzan \\ International Woman University, Jl. Baranangsiang ITC Kosambi Bandung,, fauzanahmad083@gmail.com
}

\begin{abstract}
This journal discusses the description of the lives of truck drivers represented in image and text message on the back of the truck. The image and text message become interesting since some readers feel it as a mere entertainment. However, to see the interpretation is through the perspective of linguistics. The theory of semiotics used analyze the point of view and meaning of images and writings that are represented. By using the connotation and denotation meaning contained in semiotics, the language used is analyzed. The method used in this research is qualitative to describe the statement or the existing picture. The purpose of this study is to get understanding about image and text message illustrated on the back of the truck. The conclusion is that every writing and illustration illustrated in the truck has its own purpose which leads to the attention and criticism of the society towards the development of the era so that the meaning becomes part of the representation of some people who live on the streets.
\end{abstract}

Keywords : image; text message; truck; connotation; denotation

\begin{abstract}
ABSTRAK
Dalam jurnal ini dibahas gambaran kehidupan para sopir truk yang direpresentasikan dalam gambar dan tulisan yang terdapat di belakang truk. Gambar dan tulisan ini menjadi menarik karena bagi sebagian pembaca hal ini adalah sebuah hiburan. Adapun untuk melihat penafsiran kata-kata yang digunakan dapat dilihat dari perspektif bahasanya. Teori semiotik digunakan untuk menganalisis sudut pandang dan makna dari gambar dan tulisan yang dipresentasikan. Dengan menggunakan analisis makna konotasi dan denotasi yang terdapat pada kajian semiotik, penggunaan bahasa pada tulisan tersebut dianalisis. Metode yang diguanakan dalam penelitian ini adalah kualitatif, yaitu untuk mendiskripsikan pernyataan atau gambar yang ada. Tujuan dalam penelitian ini yaitu untuk mengetahui adanya pemahaman atas tulisan dan gambar yang diilustrasikan pada gerobak truk. Simpulannya adalah setiap tulisan dan gambar yang diilustrasikan pada bagian belakang truk mempunyai maksud dan tujuan tersendiri baik yang mengarah pada perhatian maupun kritikan masyarakat terhadap pekembangan zaman sehingga makna tersebut menjadi bagian dari representasi sebagian masyarakat yang hidup diperjalanan.
\end{abstract}

Kata Kunci:gambar; pesan tulisan; truk; konotasi; denotasi 
Pendahuluan

Seiring dengan gencarnya kemajuan teknologi yang semakin canggih, serta aneka karya kreatifitas masyarakat juga semakin inovatif maka pemahaman masyarakatpun semakin terbawa oleh jaman yaitu modernisasi. Kemajuan di sini mengarah pada nilai seni kreatifitas dalam daya fikir yang dilakukan oleh sebagian masyarakat. Terlihat saat adanya suatu perubahan dari waktu ke waktu hingga menjadi trend di segala bidang, salah satu contohnya dalam pembuatan ukiran kayu dan lukisan pun dapat terbuat dari teknologi komputer yang bernuansa lebih dari sekedar indah. Hal tersebut merupakan keberlangsungan tuntutan zaman yang mengarah pada praktis dan efisien. Untuk itu, perkembangan era teknologi harus diimbangi dengan nilai manfaat sesuai dengan aturan yang berlaku. Sedangkan untuk mengukur aturan yang berlaku dapat dilihat dengan pemahaman terhadap informasi baik tanda maupun tulisan yang diterima lewat komunikasi yang tepat. Sebagaimana menurut Sobur (2013) bahwa dengan sarana tandalah manusia dapat berfikir, tanpa tanda kita tidak dapat berkomunikasi.

Dalam kehidupan sehari-hari tanda hadir dalam bentuk yang beraneka ragam, seperti simbol, lambang, kode, isyarat, sinyal dan sebagainya. Semua mempunyai unsur-unsur yang memiliki arti tertentu sehingga ia mempunyai makna dan nilai sosial. Namun pemahaman tanda tidak datang secara tiba-tiba karena adanya suatu sistem yang berlangsung sebagaimana menurut Seassure dikatakan bahwa tanda terdiri dari relasi yang terdapat pada kehidupan sosial yang berlaku. Oleh keran itu, tanda terdiri dari dua jenis bagian. Seperti dikatakan oleh Segers (2000) pertama, "tanda natural" yaitu tanda yang terjadi secara alami, kedua "tanda konvensional" yaitu tanda yang dibuat khusus untuk komunikasi. Keduanya merupakan tradisi yang pantas dihargai dan diakui secara sosial melalui ilmu semiotik.

Dalam perbincangan semiotika sebagai sebuah ilmu makna, ada semacam ruang kontradiksi yang secara historis dibangun diantara dua kubu yaitu semiotika Ferdinand de Seassure dan semiotika Charles Sanders Pierce. Seolah-olah kedua kubu tersebut saling bersebrangan layaknya oposisi biner, ada siang dan malam, signifikasi dan komunikasi serta denotasi dan konotasi. Padahal hakikatnya saling mengisi dan melengkapi pengertiannya. Oleh karena itu, setiap tanda atau simbol yang mengarah pada kehidupan sosial mempunyai pesan tersendiri yakni makna sebenarnya dan makna kiasan. Istilah lain dalam linguistik dalam kajian makna adalah semantik, Semantik diartikan sebagai ilmu tentang makna atau tentang arti, yaitu salah 


\section{Deskripsi Sosial Masyarakat terhadap Gambar dan Tulisan yang Terdapat dalam Gerobak Truk}

satu dari tiga tataran analisis bahasa: fonologi, gramatika, dan semantik (Chaer, 2013: 2). Di sini objek kajiannya adalah tulisan dan gambar yang dipresentasikan di bagian belakang sebuah truk.

Dalam hal ini, peneliti akan mencoba menganalisis suatu gambaran perjalanan masyarakat yang hidup di jalanan. Salah satu kajian ini adalah representasi terhadap gambar atau tulisan truk yang semakin menarik untuk dikaji karena mempunyai pesan dan makna untuk disampaikan oleh pembaca. Pada hakikatnya untuk sebagian orang hal tersebut merupakan hiburan dan seni untuk mendapatkan perhatian yang lebih pada gambaran kehidupan orang yang selalu transit antar kota. Seperti halnya tulisan dalam gerobak truk, tulisan tersebut akan merepresentasikan supir dari gerobak truk tersebut dari berbagai makna. Dengan adanya penelitian ini, pembaca atau pengamat gambar dan tulisan pada gerobak truk bisa lebih cermat dan tepat dalam memaknainya, bahkan bisa jadi tidak lagi memberi penilaian secara subjektif khususnya kepada sopir.

Dalam tulisan ini akan dicoba untuk menjawab pertanyaan bagaimana representasi sosial masyarakat terhadap kehidupan perjalanan yang dilambangakan pada tulisan atau gambar yang terdapat pada mobil truk sehingga memiliki pesan untuk pembaca. Dalam analisis ini peneliti menggunakan analisis linguistik dari Ferdinand d Seassure sebagai aliran strukturalisme yang menyatakan bahwa bahasa itu adalah suatu sistem tanda, dan setiap tanda itu terdiri dari dua bagian yaitu signifier 'penanda' dan signified 'petanda' (Barker, 2000). Adapun tujuan dari penulisan ini yaitu untuk mengetahui dan menganalisis pemahaman simbol atau tulisan terdapat dalam truk sehingga pembaca dapat memahami isi pesan tersebut. Dengan demikian, penulis melihat representasi dalam tulisan dan gambaran merupakan bagian dari fenomena sosial masyarakat yang mempunyai pesan dan kesan tersendiri bahkan memilki nilai daya tarik marketing secara manarik. Tanpa disadari, masyarakat yang hidup diperjalanan memiliki kepedulian baik kritik, saran, ajakan dan gambaran pada kehidupan seorang sopir truk

Penelitian ini dilakukan di salah satu desa Kabupaten Cirebon yang memiliki karya seni pembuatan tulisan atau gambar truk. Teknik pemilihan lokasi dilakukan secara sengaja dengan terlebih dahulu melakukan observasi untuk mengetahui tujuan dan teknik pembuatan karya tersebut. Kemudian dipilih salah satu karya secara acak diantara sekian banyak karya yang 
ada. Adapun yang menjadi informan adalah para pelaku pembuat karya tersebut serta beberapa supir truk. Sumber data penlitian ini adalah berupa hasil wawancara dari informan dan data-data yang diperoleh dari situs-situs internet, jurnal dan artikel lain yang berkaitan dengan penelitian ini. Teknik pengumpulan data yang digunakan dalam penelitian ini yaitu observasi, wawancara dan dokumentasi. Teknik analisis data yang digunakan yaitu analisis kualitatif.

\section{A. HASIL DAN PEMBAHASAN}

Hasil analisis menunjukkan bahwa pada dasanya bentuk karya seni tersebut mempunyai konteks atau tujuan yang sama yaitu perhatian. Beberapa contoh gambar dan tulisan truk mengarah pada konsep doa, kritikan, keluhan, serta peringatan. Fokus dalam penelitian ini adalah yang mengarah pada peringatan atau gambaran kehidupan. Pada dasarnya ilmu semiotik ilmu yang mempelajari berbagai makna terhadap suatu konteks tertentu, melalui tanda dan petanda. Bisa jadi apa yang ada dalam lingkungan masyarakat mempunyai semiotik baik berupa verbal, tulisan dan sebagainya. Kaitanya dengan verbal berarti semiotik linguistik sedangkan semiotik visual adalah mengenai gambar-gambar (Hall, 1997). Dikarenakan dalam gambar truk tersebut mencakup tulisan dan gambar, maka penelitian ini menggunakan semiotik linguistik dan visual. Penulis melihat katakata dan gambar yang terdapat belakang truk sebagai seni kreatif yang mempunyai makna polisemi "bermakna banyak" bisa berarti pesan supir, pengalaman, keluhan, dan pengharapan selama menjalani kehidupan di perjalanan yang terkesan bahwa sang supir jarang bisa untuk pulang dan berkumpul dengan keluarganya. Berikut deskripsi dari gambar dan tulisan yang terdapat belakang truk

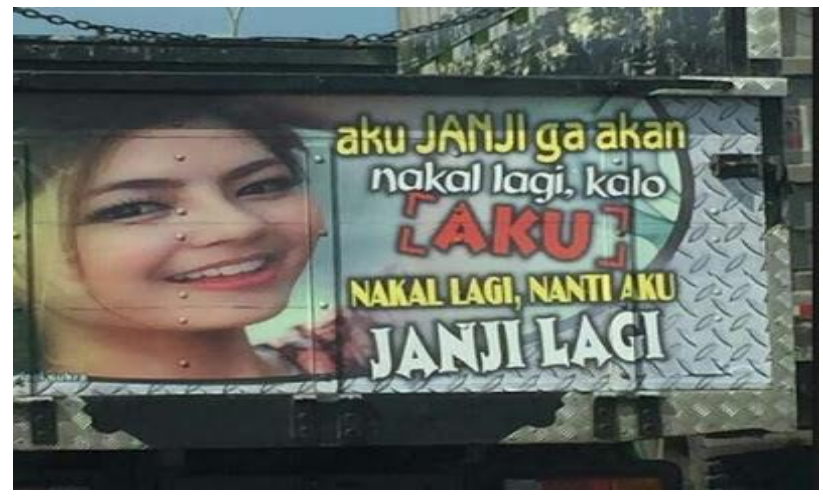

Dalam gambar tersebut, secara sekilas bermaksud menggambarkan sosok kehidupan seoarang supir yang mengarah pada kenakalan hidup dijalanan terutama dalam bermain perempuan. Kenapa demikian karena bahasa itu adalah suatu sistem tanda dan setiap tanda itu tersusun dua bagian yaitu signifier (penanda) dan signified (petanda). Dengan kata lain, petanda atau penanda adalah sebuah coretan atau gambar yang bermakna. Suatu penanda 


\section{Deskripsi Sosial Masyarakat terhadap Gambar dan Tulisan yang Terdapat dalam Gerobak Truk}

tanpa petanda tidak berarti apa-apa dan karena itu tidak merupakan tanda begitupun sebaliknya. Penanda dan petanda merupakan kesatuan seperti dua sisi dari sehelai kertas, kata Seasure (Piliang, 1999). Penanda atau petanda disini adalah dapat berbagai macam sudut pandang, pertama, teks tersebut sebagai representasi dari seoarang supir, kedua, teks tersebut bisa jadi representasi dari seoarang perempuan yang di gambar, ketiga teks tersebut dapat juga representasi dari seorang istri supir untuk mengingatkan suaminya yang hidup di jalanan, yang semuanya bergantung bagaimana memaknai dengan perspektif yang tepat. Salah satu yang peneliti kaji adalah secara denotasi dan konotasi yang mengarah pada satu sudut pandang tertentu.

Sekarang, bagaimana menganalisis gambar dan tulisan? Membuat kajian analisis gambar atau tulisan adalah bagian dari jenis teks yang berupa pesan ataupun sekedar hiburan belaka (Christomy, 2001). Maka itu, pembahasan ini menggunakan kajian kritis yang bertujuan mengungkap makna atau simbol-simbol yang ada utamanya adalah visual dan kata-kata. Peneliti mengambil objek visual dan tulisan yang ada pada belakang truk. Objek tersebut menguak makna visual dan tulisan yang berbagai persoalannya menyangkut permasalahan yang berkembang dalam masayarakat, khususnya masalah kehidupan para supir di jalanan.

Langkah pertama, menurut Christomy, kita mesti dapat menggambarkan jalinan antara visual dan tulisan tersebut. Misalkan dapat menandainya dengan pola kata-kata yang direpresentasikan dengan gambar perempuan yang cantik, karena perempuan cantik di sini lebih cenderung dengan menggoda semua laki-laki. Mengapa demikian, karena mendapatkan perempuan cantik adalah idaman semua para laki-laki, namun kecantikan yang dimaksud di sini adalah secara fisik. Seperti diungkapkan Bungin (2007: 221) bahwa kecantikan direpresentasikan dalam rupa kulit whiteness (menjadi putih), rambut hitam, tebal dan lurus, bertubuh slim, memiliki kesegaran tubuh, adanya kebersihan, kemewahan, keanggunan dan berparas menawan. Sementara itu, Prabasmoro (2003:106) dalam bukunya mengungkapkan bahwa kecantikan dinaturalisasikan dengan warna kulit putih.

Ilustrasi tersebut memunculkan adanya suatu kedekatan antara kata-kata dengan perempuan cantik, berdasarkan pengamatan sekilas bahwa tulisan tersebut merepresentasikan supir yang sering lalai dalam menjaga kesetiaan seorang istri. Komposisi teks tersebut merupakan 


\section{Jurnal al-Tsaqafa Volume 15, No. 01, Juli 2018}

perpaduan yang saling menunjang seakan representasi kelalaian janji oleh seorang sopir karena perempuan cantik. Hal ini dapat dikatakan bahwa gambar dan tulisan tersebut tampil sebagai tanda karena ada kedekatan yang saling merepresentasikan.

Apabila mencermati kedua wacana tersebut melalui gambar perempuan cantik, dan sebuah tulisan memuat kata janji, proporsi yang dapat ditemukan adalah sebuah peringatan yang disisipi dengan indeksikal pada hiburan "canda" dengan sebuah tanda yang bentuk tulisan yang berwarna dan tidak beraturan. Dengan demikian, suatu penanda yang dimaksud adalah gambar perempuan cantik dan jenis tulisan yang bervariasi, kemudian menimbulkan petanda yang mengartikan pada pemikiran kita yaitu gambaran kehidupan supir yang identik dengan setiap perjalanan menemukan perempuan cantik. Dengan penanda dan petanda kata janji dan gambar perempuan cantik, maka di sisi inilah bagian dari hiburan yang menarik terhadap petanda yang ada dalam pemikiran pembaca.

Sedangkan dari sudut interpretasi, kalimat tersebut adalah sebuah proporsi. Artinya suatu teks yang siap dan terbuka untuk dimaknai dengan realitas atau tanda. Teks diilustrasikan dengan gambar perempuan cantik yang bertujuan untuk daya tarik pembaca di jalanan. Intrepretasi yang dimaksud yaitu adanya suatu keterpaduan antara makna tulisan yang direpresentasikan dengan gambar perempuan. Bahkan bisa jadi andai kata bukan "janji" mungkin ilustrasinya dengan proporsi perempuan biasa. Proporsi yang dimaksud adalah makna kata-kata dengan daya tarik pembaca untuk mendapatkan arti gambaran kehidupan seorang supir bahkan pembuat karya seni. Hasilnya cukup menarik dengan adanya tanda visual "perempuan cantik" dan tanda verbal yang bertuliskan "janji". Hal ini memiliki proporsi visual diperpadukan dengan proporsi verbal. Dengan demikian dua buah proporsi tersebut menjadi argumen masyarakat dan argument tersebut merupakan tema utama dalam gambar truk yang berarti peringatan dengan cara menghibur baik isi tulisannya maupun gambar perempuannya.

Salah satu cara yang digunakan para ahli untuk membahas lingkup makna yang lebih besar adalah dengan membedakan antara denotatif "leksikal" dan konotatif "kiasan". Makna denotasi lebih bersifat langsung, yaitu khusus yang terdapat dalam sebuah tanda dan pada intinya dapat disebut dengan gamabaran petanda (Barger, 2000). Sedangakan konotasi secara tidak langsung lebih mengarah pada aspek makna dari sekelompok kata yang didasarkan atas perasaan yang timbul dari pembicara dan 


\section{Deskripsi Sosial Masyarakat terhadap Gambar dan Tulisan yang Terdapat dalam Gerobak Truk}

pendengar. Dalam hal ini memiliki teks yang berupa gambar dan tulisan, dalam tulisan tersebut secara denotasi yang berulang-ulang untuk berbuat salah tetapi berusaha mengulangi kembali, namun diekspresikan dengan petanda yang bermakna canda yang terpusat pada kata “aku janji”. Seakan aku disini mengarah pada supir truk, sedangakan denotasi gambar tersebut mengarah sebagai penggoda karena direpresentasikan dengan perempuan cantik. Berbeda dengan konotasi, dalam teks tulisan dapat diartikan dengan perumpamaan yang memiliki arti secara tidak langsung "aku janji." yang berarti subjektif terhadap citra seorang supir yang nakal, dapat juga yang dimaksud nakal adalah gambar perempuannya. Dalam konotasi bermakna bermacam-macam perspektif bergantung dari berbagai macam sudut pandang, bahkan kata-kata tersebut sebatas hiburan bukan mengarah pada peringatan. Gambar perempuan tersebut memiliki arti untuk mengingatkan para supir supaya diperjalanan berbagai macam jenis godaan yang diilustrasikan dengan tulisan dan gambar yang saling memberi pengertian yang berbeda.

Pada dasarnya pembahasan denotasi dan konotasi tidak memiliki pengertian yang sama, karena denotasi bersiafat objektif dan secara umum. Sedangkan konotasi bersifat subjektif yang dapat menimbulkan multitafsir terhadap hubungan gambar dan tulisan yang akan menimbulkan perbedaan persepsi masingmasing. Teks tersebut memiliki suatu rangkaian kata-kata yang mempunyai arti untuk menghibur sekaligus mengingatkan. Konotasi lebih cenderung pada nilai emosional yang berarti pergeseran makna, makanya hampir semua orang tidak dapat mengerti mengenai makna tersendiri. Sementara peneliti hanya mengambil contoh pengetian konotasi secara gambaran umum atau tidak mengarah pada ideologi tertentu.

\section{B. SIMPULAN}

Teks merupakan ilustrasi pesan yang mempunyai makna tersendiri baik secara langsung maupun tidak langsung. Teks dalam gambar truk dan tulisan tersebut lebih mengarah pada sebuah hiburan belaka yang berisi mengingatkan sekaligus meberikan kehidupan di jalanan. Peneliti telah mendapatkan beberapa simpulan yaitu, pertama adanya suatu nilai seni dengan menggunakan tulisan yang variatif dan bergambar perempuan cantik, kedua antara tulisan dan gambar tersebut memiliki keterpaduan makna yang menghasilkan sebuah tanda dan petanda yang ada dalam pemikiran pembaca sehingga petanda 
tersebut ada di dalam pemikiran pembaca utamanya, yaitu kehidupan seorang sopir truk. Selanjutnya makna denotasi dan konotasi dalam teks tersebut lebih cenderung berbeda karena berkaitan umum dan khusus dalam rangka cara memaknai teks. Denotasi lebih mengarah pada kehidupan sopir truk yang sering janji dan menggambarkan perempuan cantik sebagai penggodanya. Sedangkan konotasi lebih mengarah pada berbagai macam perspektif pembaca dalam memaknai teks tersebut, salah satunya dengan menggunakan subjektifitas dalam memaknai teks tersebut.

\section{DAFTAR PUSTAKA}

Barger, Peter L. dan Thomas Luckman. 1990. Tafsir Sosial atas Kenyataan; Risalah Tentang Sosiologi Pengetahuan. Jakarta: LP3ES

Barker, Chris 2000. Cultural Studies (Theory and Practice). California: Sage Publications

Burhan, M Bungin. 2008. Konstruksi Sosial Media Massa: Kekuatan Pengaruh Media Massa dan Keputusan Konsumen serta Kritik Terhadap Peter L. Berger \& Thomas Luckmann. Jakarta: Kencana

Christomy, Tommy. 2001. Pengantar Semiotik Pragmatik Peirce: Nonverbal dan Verbal dalam pusat Penelitian Kemasyarakatan dan Budaya Lembaga Penelitian Universitas Indonesia.

Chaer, Abdul.2013. Pengantar Semantik Bahasa Indonesia. Jakarta:Reineka Cipta Hall, Stuart. 1997. Representation: Cultural Representations and Signifying
Practices. London: Sage Open University

Prabasmoro, Aquarini Priyatna.2003. Becoming White: Representasi Ras, Kelas, Feminitas, dan Globalisasi dalam Iklan Sabun. Yogyakarta: Jalasutra

Piliang, Yasraf Amir. 1999. Sebuah Dunia yang Dilipat; Realitas Kebudayaa Menjelang Milenium Ketiga dan Matinya Posmodernisme. Bandung: Mizan

Segers, Rein T. 2000. Evaluasi Teks Sastra. Yogyakarta: Adicita Karya Nusa

Sobur, Alex. 2013. Semiotika Komunikasi. Bandung:Rosdakarya 